\title{
New compostable tubes for the production of high quality seedlings of three species of Mimosa spp
}

\author{
Nuevo tubo compostable para la producción de plántulas de calidad \\ de tres especies de Mimosa spp
}

\begin{abstract}
Anna Cecília Ferreira Stremel a, Fernanda Neves Lima a, Marta Regina Barrotto do Carmo a, Rosimeri de Oliveira Fragoso ${ }^{\text {a*}}$, Carlos André Stuepp ${ }^{\text {b }}$

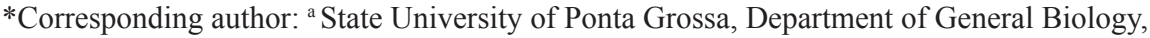
Ave. General Carlos Cavalcanti, 4748, Ponta Grossa, Paraná, Brazil, tel.: 55-42-32203126, meri_ol@yahoo.com.br

${ }^{\mathrm{b}}$ State University of Ponta Grossa, Department of Phytotechnics and Plant Health, Ponta Grossa, Paraná, Brazil.
\end{abstract}

SUMMARY

Obtaining high-quality native species seedlings and sustainable alternatives for seedling production are currently some of the bottlenecks for successful restoration plantings in degraded ecosystems. This study evaluated the survival and vigor of seminal seedlings of Mimosa flocculosa, M. micropteris and M. incana, produced in three containers $\left(110 \mathrm{~cm}^{3}\right.$ and $55 \mathrm{~cm}^{3}$ polypropylene tubes and $58 \mathrm{~cm}^{3}$ SISBGC type biocompostable container) for ecological restoration purposes in the phytogeographic region of Mixed Ombrophilous Forest. Survival, total height, stem diameter, shoot and root dry biomass, sturdiness quotient, Dickson's quality index and technical efficiency were evaluated. Survival percentages were higher for the three Mimosa species throughout all evaluations and in the three containers, with an average over $95 \%$, demonstrating the viability of the seedling production protocol used. Although the $110 \mathrm{~cm}^{3}$ tube favored larger seedling growth, especially in M. flocculosa, the SISBGC tube showed similar efficiency for M. micropteris and M. incana. We conclude that a good performance in the nursery, associated with the bio-decomposition characteristics, makes SISBGC an excellent alternative for producing native seedlings for ecological restoration purposes.

Keywords: biodegradable tube, native species of Brazil, ecological restoration, forest nurseries, Mixed Ombrophilous Forest.

\section{RESUMEN}

La obtención de plántulas de especies nativas de alta calidad, así como alternativas sostenibles para la producción de plántulas, representan hoy algunas de las limitaciones para el éxito de las plantaciones de restauración de ecosistemas degradados. Así, el objetivo fue evaluar la supervivencia y vigor de plántulas seminales de Mimosa flocculosa, M. micropteris y M. incana, producidas en tres recipientes (tubos de polipropileno de $110 \mathrm{~cm}^{3}$ y $55 \mathrm{~cm}^{3}$ y recipiente biocompostable tipo SISBGC de $58 \mathrm{~cm}^{3}$ ), con fines de restauración ecológica en una región fitogeográfica de Bosque Mixto Ombrófilo. Se evaluó la supervivencia, altura, diámetro del tallo, biomasa de tallo seco y raíz, coeficiente de robustez, índice de calidad de Dickson y eficiencia técnica. Hubo altos porcentajes de supervivencia para las tres especies del género Mimosa a lo largo de todas las evaluaciones y en los tres paquetes utilizados, con un promedio superior al $95 \%$, demostrando la viabilidad del protocolo de producción de plántulas utilizado. Si bien el tubo de 110 $\mathrm{cm}^{3}$ favoreció un mayor crecimiento de plántulas, principalmente en M. flocculosa, para M. micropteris y M. incana, el tubo SISBGC mostró una eficiencia similar. Así, el buen desempeño en vivero, asociado a la característica de biodecomposición, hacen del SISBGC una excelente alternativa para la producción de plántulas nativas con fines de restauración ecológica.

Palabras clave: tubos biodegradables, especies nativas de Brasil, Bosque Mixto Ombrófilo, restauración de ecosistemas degradados, viveros forestales.

\section{INTRODUCTION}

The Fabaceae family, popularly known as legumes, is currently divided into six subfamilies (LPWG 2017). Five of these families are represented in Brazil, comprising 253 genera and 3,033 species (Flora do Brasil 2020). Many of its species are associated with nitrogen-fixing bacteria, which form root nodules that improve soil physical, che- mical and biological properties (Marchetti and Barp 2015). Among the subfamilies, Caesalpinioideae has 73 genera in Brazil, being Mimosa sp. the second most expressive genus, with about 373 species (Dutra et al. 2020).

The genus Mimosa is a functionally important group, characterized by fast growing species and good vegetative regeneration capacity, giving species a high potential for their use to recovering degraded ecosystems (Doura- 
do et al. 2013). Many species are pioneers and can colonize disturbed sites, acting as nucleating species by improving soil quality and facilitating the establishment of other plants (Brancalion et al. 2015). Currently, vigorous pioneer species are valuable for the initial phase of ecosystem recovery, as their competitive capacity is an enormous advantage over colonization by species that inhibit natural regeneration, e.g., many invasive grass species (Fragoso et al. 2017). For example, the species Mimosa flocculosa Burkart, Mimosa micropteris Benth. and Mimosa incana Benth. are considered important components for restoring Permanent Preservation and Legal Reserve Areas in Brazil (Carpanezzi and Zanona 2017).

Among the challenges of ecological restoration is the growing demand for native species in forest nurseries, which points to the need to develop research that optimizes the production of quality seedlings that can meet the objectives of plantations (Grossnickle 2016). Several factors guide seedling production in forest nurseries to provide higher survival in the field. Among the main factors, the type of container and its dimensions highly influence forest species seedling quality and production costs, being significant for plant growth (Pias et al. 2015). A suitable container must ensure the proper development of the root system until the seedling dispatch stage, generating good architecture and aggregating roots to the substrate, and thus favoring the survival and initial growth of seedlings in the field (Freitas et al. 2018).

Many containers are used to produce native species seedlings, from traditional "plastic bags" to biodegradable materials, with rigid plastic tubes being the most commonly used material. The wide use of these tubes has been justified by lower substrate consumption and optimization of time and production area and the ease of field transport and good root system formation (Cabreira et al. 2021). In contrast, the need to disinfect packaging, high shipping costs and damage to the root system have required viable alternatives to this production system. To overcome these limitations, certain biodegradable materials have recently emerged on the market (Ferraz et al. 2015, Harris et al. 2020); however, such materials require high investments by forest nurseries including structural modifications to adapt the production system. Recently, the compostable germinating cradle (SISBGC) is an alternative to traditional production systems in rigid plastic tubes, adapting to traditional production structures and offering the advantages of already consolidated biodegradable materials.

To determine the quality of forest seedlings used in reforestation programs, morphological and physiological variables can be used, both of which are defined by genetic (propagule) and environmental factors such as cultural treatments in the nursery (Grossnickle and MacDonald 2018). Among the morphological variables, shoot height, stem diameter and dry shoot and root biomasses stand out as the most common to assess the quality of seedlings in the nursery (Grossnickle and MacDonald 2017). These va- riables, in turn, can be used to calculate indices such as the sturdiness quotient (H/SD) and Dickson quality index (DQI), which make it possible to assess the growth balance of seedlings and provide a measure of their performance potential in the field (Gomes et al. 2019).

Thus, considering all the highlighted aspects, the objective of this study was to evaluate the survival and vigor of seminal seedlings of M. flocculosa, M. micropteris and M. incana, produced in SISBGC tubes $\left(58 \mathrm{~cm}^{3}\right)$ and polypropylene tubes with two separate volumes (55 and 110 $\mathrm{cm}^{3}$ ), to restore degraded ecosystems.

\section{METHODS}

The experiment was conducted between August and November 2019, at the premises of the Forest Nursery of State University of Ponta Grossa (UEPG), in the municipality of Ponta Grossa (Paraná, Brazil) $\left(25^{\circ} 5^{\prime} 40^{\prime \prime} \mathrm{S}\right.$, $\left.50^{\circ} 9^{\prime} 48^{\prime \prime} \mathrm{W}, 956 \mathrm{~m}\right)$. The region climate is Cfb type, characterized as humid subtropical, with mild summers and average temperature around $18{ }^{\circ} \mathrm{C}$, and a maximum of 24 ${ }^{\circ} \mathrm{C}$ and a minimum of $13{ }^{\circ} \mathrm{C}$. The average annual rainfall for the region ranges between $1,500 \mathrm{~mm}$ and $1,800 \mathrm{~mm}$, with rainfall distributed evenly throughout the year and frosts occurring in autumn and winter.

Three shrubby species of the Fabaceae family $M$. flocculosa, M. micropteris and M. incana were evaluated. The ecology laboratory of Embrapa Florestas provided the seeds. Before the experiments, seeds were disinfected in $1 \%$ sodium hypochlorite solution $(\mathrm{NaClO})$ for 3 minutes. Subsequently, the seeds were subjected to dormancy breakage by immersion in $80^{\circ} \mathrm{C}$ water, which was allowed to cool for 24 hours.

Seeds were sowed in three different containers (treatments) as follows: I - $58 \mathrm{~cm}^{3}$ SISBGC (Intelligent and Sustainable Compostable Germinator Cradle System) type biodegradable tubes, II $-55 \mathrm{~cm}^{3}$ polypropylene tubes, III - $110 \mathrm{~cm}^{3}$ polypropylene tubes. The containers were filled with Carolina Soil ${ }^{\circledR}$ commercial substrate (composed of Sphagnum peat), expanded vermiculite, dolomitic limestone, agricultural gypsum and NPK fertilizer, with $4 \mathrm{~kg} \mathrm{~m}^{-3}$ of Osmocote ${ }^{\circledR} 5-6 \mathrm{M}$ (NPK 18-5-9).

Sowing was performed manually, using two seeds per container covered with a $0.2 \mathrm{~cm}$ layer of vermiculite. Afterwards, the containers were kept in a shade house for 60 days $(70 \%$ shading and micro-sprinkler irrigation, with four daily irrigations that lasted for 5 minutes and flow rate of $144 \mathrm{~L}_{\text {hour }}{ }^{-1}$ ). After 30 days in the shade house, the seedlings were thinned, keeping the taller and more centralized seedlings in the container.

Starter fertigation was carried out 30 days after sowing by applying $5 \mathrm{~L}$ of a solution composed of $0.15 \mathrm{~g} \mathrm{~L}^{-1} \mathrm{am}-$ monium sulfate, $2.3 \mathrm{~g} \mathrm{~L}^{-1}$ of Yoorin $\mathrm{MG}, 1.6 \mathrm{~g} \mathrm{~L}^{-1}$ potassium chloride and $0.25 \mathrm{~g} \mathrm{~L}^{-1}$ of FTE BR $10(7 \% \mathrm{Zn}, 4 \%$ $\mathrm{Fe}, 4 \% \mathrm{Mn}, 0.1 \% \mathrm{Mo}, 2.5 \% \mathrm{~B}, 0.8 \% \mathrm{Cu}$ ) to 1,000 seedlings. At 45 and 60 days after sowing, $5 \mathrm{~L}$ of growth fer- 
tilizer composed of $4 \mathrm{~g} \mathrm{~L}^{-1}$ urea, $3 \mathrm{~g} \mathrm{~L}^{-1}$ of Yoorin $\mathrm{MG}$, $3 \mathrm{~g} \mathrm{~L}^{-1}$ of potassium chloride and $0.25 \mathrm{~g} \mathrm{~L}^{-1}$ of FTE BR 10 were applied to 1,000 seedlings. At 75 days after sowing, rustification fertilization was performed by applying $5 \mathrm{~L}$ of a solution composed of $4 \mathrm{~g} \mathrm{~L}^{-1}$ of ammonium sulfate, $10 \mathrm{~g}$ $\mathrm{L}^{-1}$ of Yoorin $\mathrm{MG}, 4 \mathrm{~g} \mathrm{~L}^{-1}$ of potassium chloride and $1 \mathrm{~g} \mathrm{~L}^{-1}$ of FTE BR 10 to 1,000 seedlings.

After 60 days in a shade house, the seedlings were transferred to the rustification area (full sun and microsprinkler irrigation, with two daily irrigations lasting 10 minutes and flow of $144 \mathrm{~L}_{\text {hour }}{ }^{-1}$ ), where they stayed for 105 days.

Throughout the experiment, the variables survival, total height $(\mathrm{H})$, stem diameter (SD), shoot dry biomass (SDB), root dry biomass (RDB) and total dry biomass (TDB) were evaluated. Survival and total height were evaluated at 30, 60, 90 and 105 days after sowing. Stem diameter was measured at 60,90 and 105 days after sowing. At 105 days after sowing, four plants were selected per sampling unit to evaluate the shoot dry biomass, root dry biomass and total dry biomass. Dry biomasses were obtained by drying the material in an oven for 48 hours at $65{ }^{\circ} \mathrm{C}$, with subsequent weighing on an analytical scale with precision of $0.001 \mathrm{~g}$. From this data, the sturdiness quotient $(\mathrm{H} / \mathrm{SD})$ was calculated for each species at 60,90 and 105 days. The Dickson quality index was determined by the following formula [1]:

$$
D Q I=\frac{T D B}{\left(\frac{H}{S D}\right)+\left(\frac{S D B}{R D B}\right)}
$$

Where,

$D Q I=$ Dickson quality index.

$T D B=$ Total dry biomass $(\mathrm{g})$.

$S D B / R D B=$ Shoot-to-root dry biomass ratio

$H / S D=$ Sturdiness quotient.

Additionally, for the quantitative classification of treatments for each species, technical efficiency was calculated at 105 days, according to the following formula [2] adapted from Kratz et al. (2016):

$$
\begin{aligned}
T E= & (T D B * 0.45)+(S D B * 0.25)+(R D B * 0.10)+ \\
& (S D * 0.10)+(H * 0.10)
\end{aligned}
$$

Where,

$T E=$ technical efficiency.

$T D B=$ Total dry biomass $(\mathrm{g})$.

$S D B=$ Shoot dry biomass $(\mathrm{g})$.

$R D B=$ Root dry biomass $(\mathrm{g})$.

$S D=$ Stem diameter.

$H=$ Total height

Following a completely randomized design, the experiment was installed in a split-plot design, with four replicates of 20 seedlings per experimental unit. The main plots corresponded to the three containers, and the subplots to the four evaluation periods $(30,60,90$ and 105 days). The treatment variances were evaluated for homogeneity by the Bartlett Test $(P<0.05)$. The variables with significant differences $(P<0.05)$ in the variance analysis (ANOVA) had their means compared by the Tukey test $(P<0.05)$.

\section{RESULTS}

We found high survival percentages for the three $M i$ mosa species in all evaluations and the three different containers, with an average of $96.5 \%$. The analysis of variance (ANOVA) revealed a significant interaction between the factors container and periods evaluated only for the height of M. flocculosa and M. incana, which showed higher growth in the three container types from 90 days of evaluation (Table 1). In M. micropteris, despite the absence of interaction between the variables, there was a significant increase in height over the three evaluations, reaching a final height that was higher than that obtained for the other species.

In general, superior height and diameter values were obtained for the species M. flocculosa in the $110 \mathrm{~cm}^{3}$ tubes (Table 1 and Figure 1). For M. micropteris, SISBGC and $110 \mathrm{~cm}^{3}$ tubes showed similar growth in diameter and higher growth than that shown by the $55 \mathrm{~cm}^{3}$ tube; however, they presented no statistical differences for height. Similar height values were also found between SISBGC and 110 $\mathrm{cm}^{3}$ tubes for $M$. incana, which showed no differentiated growth in diameter in any of the containers. Considering the increase in diameter over the evaluated periods, only $M$. incana maintained the same growth pattern in all evaluations.

Analyzing the $\mathrm{H} / \mathrm{SD}, \mathrm{SDB}, \mathrm{RDB}$ and DQI at 105 days of evaluation, no statistical differences were observed among the containers for any of the three species studied (Table 2). Only for TDB and TE, higher values were observed for M. flocculosa in $110 \mathrm{~cm}^{3}$ tubes and did not repeat for the other species. It should be noted that the TDB values obtained for M. flocculosa in $110 \mathrm{~cm}^{3}$ tubes did not differ from the SISBGC values.

The correlation analysis presented in Table 3 reveals that stem diameter, TDB, SDB and RDB were determinant for the values obtained from DQI and TE for the three species studied. However, total height was positively correlated to TE only, in all three species, which was also verified for H/SD in M. flocculosa.

\section{DISCUSSION}

The high survival for the three Mimosa species in the three containers studied demonstrates the viability of the seedling production protocol used and highlights how well the species adapted to the environmental conditions in the shade house and full sun. This is also evidenced by 
Table 1. Total height of M. flocculosa, M. micropteris and M. incana seedlings at 30,60, 90 and 105 days of evaluation, in three different containers: $58 \mathrm{~cm}^{3}$ SISBGC tube, $55 \mathrm{~cm}^{3}$ and $110 \mathrm{~cm}^{3}$ polypropylene tubes.

Altura de las plántulas de M. flocculosa, M. micropteris y M. incana a los 30, 60, 90 y 105 días de evaluación, en tres paquetes diferentes: tubo SISBGC de $58 \mathrm{~cm}^{3}$, tubos de polipropileno de $55 \mathrm{~cm}^{3} \mathrm{y} 110 \mathrm{~cm}^{3}$.

\begin{tabular}{|c|c|c|c|c|c|c|}
\hline \multirow{3}{*}{$\begin{array}{c}\text { Containers } \\
58 \mathrm{~cm}^{3} \text { SISBGC }\end{array}$} & \multicolumn{4}{|c|}{ Total height $(\mathrm{cm})-$ M. flocculosa } & \multirow{2}{*}{\multicolumn{2}{|c|}{ Means }} \\
\hline & 30 days & 60 days & 90 days & 105 days & & \\
\hline & $2.09 \mathrm{aC}$ & $4.59 \mathrm{bB}$ & $10.96 \mathrm{bA}$ & $11.94 \mathrm{bA}$ & 7.40 & \\
\hline $55 \mathrm{~cm}^{3}$ polypropylene tube & $1.96 \mathrm{aC}$ & $4.82 \mathrm{abB}$ & $9.46 \mathrm{bA}$ & $10.64 \mathrm{bA}$ & 6.72 & \\
\hline $110 \mathrm{~cm}^{3}$ polypropylene tube & $2.28 \mathrm{aD}$ & $6.39 \mathrm{aC}$ & $17.93 \mathrm{aB}$ & 20.26 aA & 11.71 & \\
\hline Means & 2.11 & 5.27 & 12.78 & 14.28 & & \\
\hline \multicolumn{7}{|c|}{ Coefficient of variation $(a)=10.86 \%(b)=9.96 \%$} \\
\hline \multirow{2}{*}{ Containers } & \multicolumn{4}{|c|}{ Total height $(\mathrm{cm})-$ M. micropteris } & \multirow{2}{*}{\multicolumn{2}{|c|}{ Means }} \\
\hline & 30 days & 60 days & 90 days & 105 days & & \\
\hline $58 \mathrm{~cm}^{3}$ SISBGC & 2.54 & 11.53 & 26.44 & 29.61 & 17.53 & $\mathrm{a}$ \\
\hline $55 \mathrm{~cm}^{3}$ polypropylene tube & 2.26 & 10.38 & 23.99 & 23.19 & 14.95 & $\mathrm{~b}$ \\
\hline $110 \mathrm{~cm}^{3}$ polypropylene tube & 2.55 & 10.47 & 24.97 & 25.85 & \multirow{2}{*}{\multicolumn{2}{|c|}{$15.96 \mathrm{ab}$}} \\
\hline Means & $2.45 \mathrm{C}$ & $10.79 \mathrm{~B}$ & $25.13 \mathrm{~A}$ & $26.21 \mathrm{~A}$ & & \\
\hline \multicolumn{7}{|c|}{ Coefficient of variation $(a)=11.76 \%(b)=16.42 \%$} \\
\hline \multirow{2}{*}{ Containers } & \multicolumn{4}{|c|}{ Total height $(\mathrm{cm})-M$. incana } & \multirow{2}{*}{\multicolumn{2}{|c|}{ Means }} \\
\hline & 30 days & 60 days & 90 days & 105 days & & \\
\hline $58 \mathrm{~cm}^{3}$ SISBGC & $2.96 \mathrm{aC}$ & $9.02 \mathrm{aB}$ & 18.37 aA & 20.51 aA & 12.71 & \\
\hline $55 \mathrm{~cm}^{3}$ polypropylene tube & $2.77 \mathrm{aC}$ & $7.64 \mathrm{aB}$ & $14.66 \mathrm{bA}$ & $15.21 \mathrm{bA}$ & 10.07 & \\
\hline $110 \mathrm{~cm}^{3}$ polypropylene tube & $3.05 \mathrm{aC}$ & $9.15 \mathrm{aB}$ & $18.20 \mathrm{aA}$ & $19.55 \mathrm{aA}$ & 12.49 & \\
\hline Means & 2.93 & 8.60 & 17.07 & 18.42 & & \\
\hline
\end{tabular}

Coefficient of variation $(\mathrm{a})=12.67 \%(\mathrm{~b})=23.54 \%$

Means followed by the same lowercase letter in column and capital letter on the line do not differ between them by Tukey's test $(P<0.05)$. Los promedios seguidos de la misma letra minúscula en la vertical y letras mayúsculas en la horizontal no difieren significativamente entre sí mediante la prueba de Tukey $(P<0,05)$.

the growth in height and diameter obtained in the three evaluations (Table 1 and Figure 1). The higher values of height and diameter observed in the $110 \mathrm{~cm}^{3}$ tube compared to the $55 \mathrm{~cm}^{3}$ tube reinforce results that point to better development of the root system in larger containers since there is more space for roots to distribute and more nutrients available for absorption by seedlings (Feletti et al. 2020). However, the efficiency of the $58 \mathrm{~cm}^{3}$ SISBGC tube (which is sometimes comparable to the $110 \mathrm{~cm}^{3}$ tube in this study about the diameter and height values obtained for M. micropteris and M. incana, respectively) demonstrates that not only is the volume of the container important for adequate development of the root system, but the container morphology could also lead to quality seedlings in the nursery since the quality of the root system is related to the adequate stem development. According to some authors, the quality standard of seedlings is highly correlated to the height and diameter of the stem, determining higher survival and growth rates in field (Grossnickle and MacDonald 2017, Freitas et al. 2018).

Another aspect worth mentioning is the composition of the SISBGC tube, which comprises about $80 \%$ calcium carbonate $\left(\mathrm{CaCO}_{3}\right)$, of which approximately $50 \%$ is converted into $\mathrm{CO}_{2}$ and the rest into $\mathrm{CaO}$. Carbon dioxide can interact with water and release hydrogen ions $\left(\mathrm{H}^{+}\right)$, reducing the $\mathrm{pH}$ of the substrate, with cations available for root absorption. In turn, calcium is considered an important macronutrient for vegetables. It is a constituent of cell walls, particularly the middle lamella, and also required for cell division, and therefore, for better seedling growth. In addition, it contributes to higher solubility of other nutrients, increasing the cation exchange capacity (CTC) of the substrate (Thor 2019), which could be related to the results found in this study. It is noteworthy, however, that even though the holes in the sides of SISBGC tubes provide better distribution of the root system throughout the 
A
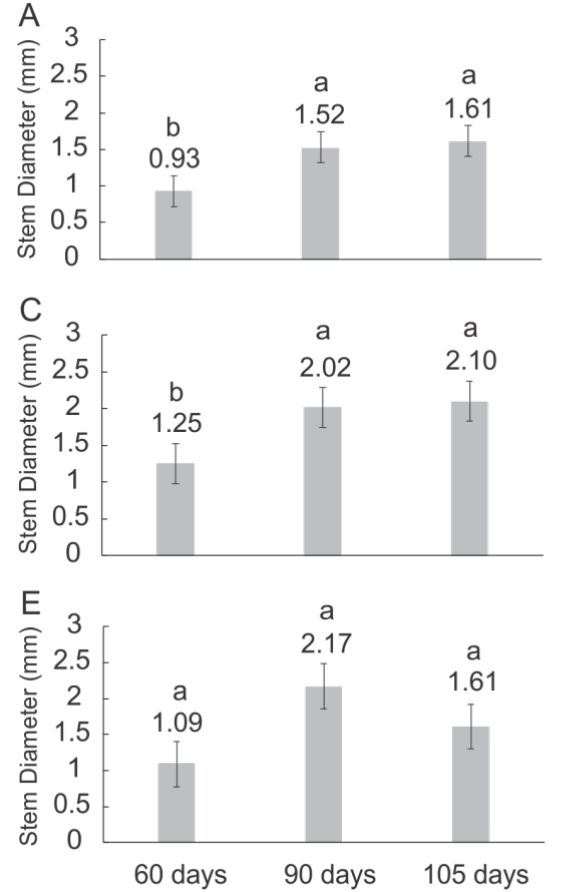

B

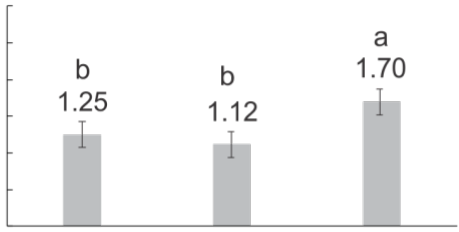

D

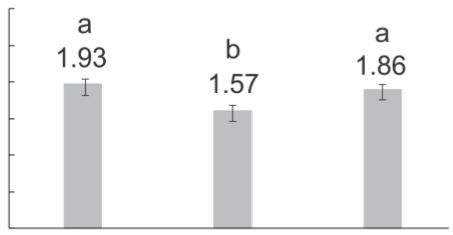

$\mathrm{F}$

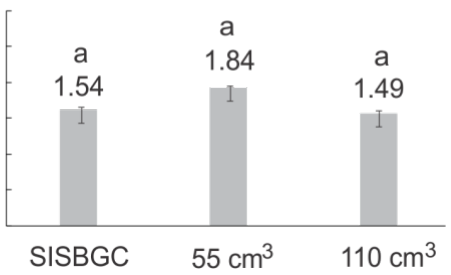

Figure 1. Stem diameter of M. flocculosa (A, B), M. micropteris (C, D) and M. incana (E, F) seedlings at 60, 90 and 105 days of evaluation and three different containers: $58 \mathrm{~cm}^{3}$ SISBGC tube, $55 \mathrm{~cm}^{3}$ and $110 \mathrm{~cm}^{3}$ polypropylene tubes. Means followed by the same letter do not differ between them by Tukey's test $(P<0.05)$. The bars indicate the standard error of the mean.

Diámetro de las plántulas de M. flocculosa (A, B), M. micropteris (C, D) y M. incana (E, F) a los 60, 90 y 105 días de evaluación, en tres paquetes diferentes: tubo SISBGC de $58 \mathrm{~cm}^{3}$, tubos de polipropileno de $55 \mathrm{~cm}^{3}$ y $110 \mathrm{~cm}^{3}$. Las medias seguidas de la misma letra no difieren significativamente según la prueba de Tukey $(P<0,05)$. Las barras indican el error estándar de la media.

Table 2. Means and standard deviation ( \pm ) of sturdiness quotient (H/SD), total dry biomass (TDB), shoot dry biomass (SDB), root dry biomass (RDB), Dickson's quality index (DQI) and technical efficiency (TE) of M. flocculosa, M. micropteris and M. incana seedlings at 105 days of evaluation, in three different containers: $58 \mathrm{~cm}^{3}$ SISBGC tube, $55 \mathrm{~cm}^{3}$ and $110 \mathrm{~cm}^{3}$ polypropylene tubes.

Medias y desviación estándar ( \pm ) del coeficiente de robustez (H/SD), biomasa seca total (TDB), biomasa de tallo seco (SDB), biomasa seca de raíces (RDB), índice de calidad de Dickson (DQI) y eficiencia técnica (TE) de las plántulas de M. flocculosa, M. micropteris y M. incana a los 105 días de evaluación, en tres paquetes diferentes: tubo SISBGC de $58 \mathrm{~cm}^{3}$, tubos de polipropileno de $55 \mathrm{~cm}^{3}$ y $110 \mathrm{~cm}^{3}$.

\begin{tabular}{|c|c|c|c|c|c|c|c|}
\hline Containers & $\mathrm{H} / \mathrm{SD}$ & TDB $(g)$ & SDB $(g)$ & RDB (g) & DQI & TE & Rank \\
\hline & \multicolumn{7}{|c|}{ M. flocculosa } \\
\hline $58 \mathrm{~cm}^{3}$ SISBGC & $8.41 \pm 0.75$ & $2.56 \pm 0.65 \mathrm{ab}$ & $1.64 \pm 0.52$ & $0.92 \pm 0.14$ & $0.25 \pm 0.06$ & $3.00 \pm 0.32 \mathrm{~b}$ & 2 \\
\hline $55 \mathrm{~cm}^{3}$ polypropylene tube & $8.33 \pm 0.91$ & $2.16 \pm 0.64 \mathrm{~b}$ & $1.50 \pm 0.53$ & $0.67 \pm 0.13$ & $0.20 \pm 0.04$ & $2.60 \pm 0.55 \mathrm{~b}$ & 3 \\
\hline \multirow[t]{2}{*}{$110 \mathrm{~cm}^{3}$ polypropylene tube } & $9.54 \pm 0.90$ & $3.49 \pm 0.38 \mathrm{a}$ & $2.41 \pm 0.32$ & $1.08 \pm 0.25$ & $0.30 \pm 0.06$ & $4.52 \pm 0.25 \mathrm{a}$ & 1 \\
\hline & \multicolumn{7}{|c|}{ M. micropteris } \\
\hline $58 \mathrm{~cm}^{3}$ SISBGC & $13.20 \pm 1.16$ & $4.31 \pm 1.30$ & $2.45 \pm 0.76$ & $1.86 \pm 0.69$ & $0.30 \pm 0.09$ & $5.92 \pm 1.02$ & 1 \\
\hline $55 \mathrm{~cm}^{3}$ polypropylene tube & $12.67 \pm 1.19$ & $3.03 \pm 0.57$ & $1.96 \pm 0.41$ & $1.07 \pm 0.19$ & $0.21 \pm 0.02$ & $4.46 \pm 0.65$ & 3 \\
\hline \multirow[t]{2}{*}{$110 \mathrm{~cm}^{3}$ polypropylene tube } & $11.59 \pm 0.26$ & $4.53 \pm 1.14$ & $2.89 \pm 0.99$ & $1.64 \pm 0.16$ & $0.34 \pm 0.08$ & $5.73 \pm 0.88$ & 2 \\
\hline & \multicolumn{7}{|c|}{ M. incana } \\
\hline $58 \mathrm{~cm}^{3}$ SISBGC & $12.12 \pm 1.29$ & $4.90 \pm 1.26$ & $2.66 \pm 0.52$ & $2.24 \pm 0.75$ & $0.37 \pm 0.10$ & $5.32 \pm 1.15$ & 1 \\
\hline $55 \mathrm{~cm}^{3}$ polypropylene tube & $11.29 \pm 0.93$ & $3.14 \pm 0.58$ & $1.75 \pm 0.27$ & $1.38 \pm 0.33$ & $0.25 \pm 0.06$ & $3.64 \pm 0.39$ & 3 \\
\hline $110 \mathrm{~cm}^{3}$ polypropylene tube & $11.04 \pm 1.13$ & $3.47 \pm 0.85$ & $2.05 \pm 0.42$ & $1.42 \pm 0.44$ & $0.28 \pm 0.08$ & $4.35 \pm 0.64$ & 2 \\
\hline
\end{tabular}

Means followed by the same letter do not differ between them by Tukey's test $(P<0.05)$.

Las medias seguidas de la misma letra no difieren según la prueba de Tukey $(P<0,05)$. 
Table 3. Correlation among biometric variables: total height, stem diameter, sturdiness quotient (H/SD), total dry biomass (TDB), shoot dry biomass (SDB) and root dry biomass (RDB) with Dickson quality index (DQI) and technical efficiency (TE) of M. flocculosa, M. micropteris and M. incana seedlings at 105 days of evaluation.

Correlación entre las variables biométricas altura total, diámetro, cociente de robustez, biomasa seca total (TDB), biomasa de tallo seco (SDB) y biomasa de raíces (RDB) con el índice de calidad de Dickson (DQI) y la eficiencia técnica (TE) de las plántulas de M. flocculosa, M. micropteris y M. incana a los 105 días de evaluación.

\begin{tabular}{|c|c|c|c|c|c|c|}
\hline & Total height & Stem diameter & $\mathrm{H} / \mathrm{SD}$ & TDB & SDB & RDB \\
\hline & \multicolumn{6}{|c|}{ M. flocculosa } \\
\hline DQI & $0.49^{\mathrm{ns}}$ & $0.59 *$ & 0.11 ns & $0.90 * *$ & $0.78 * *$ & $0.94 * *$ \\
\hline \multirow[t]{2}{*}{$\mathrm{TE}$} & $0.90 * *$ & $0.83 * *$ & $0.62 *$ & $0.92 * *$ & $0.88 * *$ & $0.77 * *$ \\
\hline & \multicolumn{6}{|c|}{ M. micropteris } \\
\hline DQI & $0.50^{\mathrm{ns}}$ & $0.77 * *$ & $-0.19^{\text {ns }}$ & $0.98 * *$ & $0.93 * *$ & $0.79 * *$ \\
\hline \multirow[t]{2}{*}{$\mathrm{TE}$} & $0.79 * *$ & $0.83 * *$ & $0.18^{\mathrm{ns}}$ & $0.97 * *$ & $0.85 * *$ & $0.89 * *$ \\
\hline & \multicolumn{6}{|c|}{ M. incana } \\
\hline DQI & $0.58^{\mathrm{ns}}$ & $0.71 * *$ & $-0.17^{\text {ns }}$ & $0.95 * *$ & $0.93 * *$ & $0.95 * *$ \\
\hline $\mathrm{TE}$ & $0.87 * *$ & $0.77 * *$ & $0.24^{\mathrm{ns}}$ & $0.97 * *$ & $0.97 * *$ & $0.95 * *$ \\
\hline
\end{tabular}

$*=P<0.05, * *=P<0.01, \mathrm{~ns}=$ not significant.

$*=P<0,05 ; * *=P<0,01 ; \mathrm{ns}=$ no significativo.

container, they also increase moisture loss in the substrate, thus requiring more frequent irrigation.

The absence of statistical difference between the H/SD of the three containers for the three species can be explained by adjusting seedling growth between the stem and root system, which is in turn related to the allocation of reserves (Grossnickle and MacDonald 2017). The lowest averages obtained for M. flocculosa reflect its lower growth in height compared to other species, a characteristic that can influence its development in the field. Some studies have considered an H/SD under 10 as ideal for good quality seedlings, with the justification that values above this could mean more important susceptibility of seedlings to tipping in the field, due to the high etiolation and reduced stem resistance (Rossa et al. 2013, Grossnickle and MacDonald 2017), or even higher difficulty in absorbing and transferring water to the upper parts, especially in field conditions, where there is superior water requirement for full initial planting establishment (Gomes et al. 2019). However, these values have been suggested for conifers, and further studies are needed to define suitable values for native species. For example, despite the better nursery development of M. micropteris and M. incana than the development shown by the species $M$. flocculosa, they presented $\mathrm{H} / \mathrm{SD}$ over 10 , ranging from 11.04 to 13.20 .

Different species may respond differently to the physical restrictions generated by the root system due to the smaller volume of the container used. These restrictions, when present, seem to be related to the interference in the synthetic functions of the root system and to its capacity to absorb water and nutrients and translocate resources, reflected in its biomass production (Judd et al. 2015). In this study, although there were no statistical differences for SDB and RDB among the three containers, the highest averages for the three species were observed in the $58 \mathrm{~cm}^{3}$ SISBGC and $110 \mathrm{~cm}^{3}$ tubes compared to the $55 \mathrm{~cm}^{3}$ tube. Only M. flocculosa showed statistical differences for TDB among the three containers. The lower value observed for the $58 \mathrm{~cm}^{3}$ SISBGC tube compared to the $110 \mathrm{~cm}^{3}$ tube may have occurred because this species is less tolerant to well-drained substrates (Carvalho 2002), as was found in SISBGC tubes, presumably causing lower growth of the species.

Regarding DQI, which considers the biomass of the different plant compartments, as well as the height and stem diameter, there are no reference values in literature for higher seedling quality of different native woody species. This may hinder the analysis of the values obtained and make further studies necessary to determine the optimal value ranges for these plants in the nursery. However, $M$. flocculosa presented a higher TE value for the $110 \mathrm{~cm}^{3}$ tube due to the higher averages obtained for TDB and SDB, representing important fractions of this index. As previously mentioned, the highest averages of TDB and SDB in this species for the $110 \mathrm{~cm}^{3}$ tube compared to the SISBGC tube are possibly related to the higher moisture loss in the latter container. However, it does not seem to be a limiting factor for M. micropteris or M. incana, where the averages for TDB, SDB and RDB are comparable to those obtained for the $110 \mathrm{~cm}^{3}$ tube. In fact, considering the TE values obtained for the three species, only in M. flocculosa did the $110 \mathrm{~cm}^{3}$ tube rank higher than the SISBGC tube, while the averages for $M$. micropteris and $M$. incana suggest that the SISBGC is possibly tied to better seedling development. 
These results are also reinforced by correlation analyses between the variables and the DQI and TE indices, which attest to the possibility of using these indices to predict the response of plants in the field. Although it is not possible to say for certain that the development of a seedling in a nursery will reflect its development in the field, several studies have reinforced that attributes such as stem diameter and root dry biomass are related to higher or lower susceptibility of seedlings to the stress of planting and ability to adapt to environmental conditions (Grossnickle and MacDonald 2018). For example, well-developed roots in dry and nutritionally poor soils are important hence plants can more efficiently capture the few available resources. However, higher heights provide a competitive advantage (i.e. access to light) in places with high weed competition, which may be more critical for seedling survival (Grossnickle and MacDonald 2017). Regarding the SISBGC tube, the highest RDB and lower SDB/RDB ratios may be related to higher moisture loss in this tube, leading the plant to develop a more branched root system to ensure better contact with the substrate and, consequently, better efficiency of water and nutrient absorption. It is assumed that the proper development of the root system, in turn, influences not only the performance of the seedling in the nursery but mainly in the field and can ensure higher survival, which is particularly important if the planting occurs in drier times when water supply becomes the most influential factor for seedling survival in the first year after planting (Grossnickle 2016).

Finally, although larger containers are often associated with better seedling development (Pias et al. 2015), they present disadvantages such as lower production per unit area and higher consumption of substrate and fertilizers, which are not as costly when using smaller containers (Feletti et al. 2020). For biodegradable packaging, costs are reduced since tubes do not need to be disinfected to be reused, as well as because seedlings do not need to be dispatched from them, and less human resources to remove the seedlings from the plastic tubes and prepare them for the expedition is required. Such maneuvering can be particularly stressful for the plant when the root system is not well attached to the substrate (Grossnickle and El-Kassaby 2016), which can be mitigated by using SISBGC tubes, as they aggregate roots better, are planted with the seedling and can lead to higher survival in field. In fact, the root system is so crucial that several studies have pointed out that regardless of the species evaluated, RDB is the variable that most influences the other variables and DQI, constituting the leading indicator of seedling quality (Rossa et al. 2013, Grossnickle and El-Kassaby 2016). Other research has also frequently found that although seedlings produced in larger packages have significantly higher heights in the nursery, this difference dissipates within a few months after planting, and seedling growth mainly depends on the quality of the root system (Feletti et al. 2020, Cabreira et al. 2021). With well-formed root systems, seedlings more efficiently absorb the nutrients made available during planting, and smaller seedlings gradually reach the larger seedlings. Thus, in addition to factors such as the possibility of reusing the production system, ease of handling and availability in the market, production costs should also be considered when choosing the container since economic viability is an important factor for seedling production.

\section{CONCLUSION}

Under the conditions in which the present work was carried out, it is concluded that the production of seminal seedlings of the species M. flocculosa, M. micropteris and M. incana is a viable method in forest nurseries, and 110 $\mathrm{cm}^{3}$ and $58 \mathrm{~cm}^{3}$ SISBGC tubes are the most recommended for obtaining quality seedlings.

It is noteworthy that the optimization of space and materials must be considered in the elaboration of seedling production protocols to reduce their time and cost of production and provide higher quality and vigor for ecological restoration plantations. Thus, although the $110 \mathrm{~cm}^{3}$ tube favors higher growth of seedlings in some cases, the SISBGC tube has comparable efficiency and can be used as a sustainable alternative for producing high quality seedlings.

\section{ACKNOWLEDGEMENTS}

To Chimarrão Bitumirim Indústria e Comércio de ErvaMate Ltda., Embrapa Florestas (National Center for Forest Research) and Correia Neto Indústria e Comércio Ltda EPP, for all the support in conducting this experiment.

\section{REFERENCES}

Brancalion PHS, Gandolfi S, Rodrigues RR. 2015. Restauração florestal. São Paulo, Brasil. Oficina de Textos. 432 p.

Cabreira GV, Leles PSS, Alonso JM, Resende AS, Cabreira WV, Sousa TJS. 2021. Controlled-release fertilizer and container volume to produce Inga laurina seedlings. Floresta e Ambiente 28(1): e20190057. DOI: https://doi. org/10.1590/2179-8087-floram-2019-0057.

Carpanezzi AA, Zanona K. 2017. Notas sobre a vassoura branca Mimosa incana (Spreng.) Benth. Colombo, Brasil. Embrapa Florestas. 29 p.

Carvalho PER. 2002. Bracatinga de Campo Mourão. Colombo, Brasil. Embrapa Florestas-Circular Técnica (INFOTECA-E). 5 p.

Dourado DAO, Conceição AS, Santos-Silva J. 2013. O gênero Mimosa L. (Leguminosae: Mimosoideae) na APA Serra Branca/Raso da Catarina, Bahia, Brasil. Biota Neotropical 13(4): 225-240. DOI: https://doi.org/10.1590/S167606032013000400020 .

Dutra VF, Morales M, Jordão LSB, Borges LM, Silveira FS, Simon MF, Santos-Silva J, Nascimento JGA, Ribas ODS. 2020. Mimosa in Flora do Brasil 2020. Jardim Botânico do Rio de Janeiro. Accessed 27 November 2020. Available in http://floradobrasil.jbrj.gov.br/reflora/floradobrasil/ FB23084. 
Feletti TA, Araújo EF, Gonçalves EO, Feletti TA, Santos AR, Gibson EL. 2020. Growth and nutrition of Paratecoma peroba seedlings in different tube volumes and controlledrelease fertilizers. Floresta 50(3): 1613-1622. DOI: https:// doi.org/10.5380/rf.v50 i3. 65120.

Ferraz MV, Cereda MP, Iatauro RA. 2015. Produção de mudas de petúnia comum em tubetes biodegradáveis em substituição aos sacos plásticos. Revista Brasileira de Engenharia de Biossistemas 9(1): 74-83. DOI: https://doi.org/10.18011/ bioeng2015v9n1p74-83.

Flora do Brasil 2020. 2020. Fabaceae in Flora do Brasil 2020. Jardim Botânico do Rio de Janeiro. Accessed 27 November 2020. Available in http://floradobrasil.jbrj.gov.br/reflora/ floradobrasil/FB115.

Fragoso RO, Carpanezzi AA, Koehler HS, Zuffellato-Ribas KC. 2017. Barreiras ao estabelecimento da regeneração natural em áreas de pastagens abandonadas. Ciência Florestal 27(4): 1451-1464. DOI: https://doi.org/10.5902/1980509830331.

Freitas TAS, Silva PSP, Peixinho JB, Mendonça AVR, Santos LB. 2018. Performance of tamboril seedlings produced in three different tube volumes. Floresta e Ambiente 25(4): e20150214. DOI: https://doi.org/10.1590/2179$\underline{8087.021415}$.

Gomes SHM, Gonçalves FB, Ferreira RA, Pereira FRM, Ribeiro MMJ. 2019. Avaliação dos parâmetros morfológicos da qualidade de mudas de Paubrasilia echinata (pau-brasil) em viveiro florestal. Scientia Plena 15(1): 1-10. DOI: https:// doi.org/10.14808/sci.plena.2019.011701.

Grossnickle SC. 2016. Restoration silviculture: An ecophysiological perspective: Lessons learned across 40 years. Reforesta 1(1): 1-36. DOI: https://doi.org/10.21750/REFOR.1.02.2.

Grossnickle SC, El-Kassaby YA. 2016. Bareroot versus container stocktypes: a performance comparison. New Forests 47(1): 1-51. DOI: https://doi.org/10.1007/s11056-015-9476-6.

Grossnickle SC, MacDonald JE. 2017. Why seedlings grow: influence of plant attributes. New Forests 49(1): 1-34. DOI: https://doi.org/10.1007/s11056-017-9606-4.

Grossnickle SC, MacDonald JE. 2018. Seedling quality: history, application, and plant attributes. Forests 9(5): 2-23. DOI:
$10.3390 / \mathrm{f} 9050283$

Harris BA, Habteselassie MY, Pennisi SV. 2020. Mineral nutrients, organic amendment, and water impact decomposition of biodegradable containers under controlled conditions. Water, Air, \& Soil Pollution 231(10): 1-13. DOI: https://doi.org/10.1007/s11270-020-04866-7.

Judd LA, Jackson BE, Fonteno WC. 2015. Advancements in root growth measurement technologies and observation capabilities for container-grown plants. Plants 4(3): 369-392. DOI: https://doi.org/10.3390/plants4030369.

Kratz D, Wendling I, Stuepp CA, Fragoso RO. 2016. Ranking of substrates based on Piptadenia gonoacantha morphological parameters. Bosque 37(2): 265-271. DOI: https://doi. org/10.4067/S0717-92002016000200005.

LPWG (The Legume Phylogeny Working Group). 2017. A new subfamily classification of the Leguminosae based on a taxonomically comprehensive phylogeny. Taxon 66(1): 4477. DOI: https://doi.org/10.12705/661.3.

Marchetti MM, Barp EA. 2015. Efeito rizosfera: a importância de bactérias fixadoras de nitrogênio para o solo/planta - revisão. Ignis 4(1): 61-71.

Pias OHC, Berghetti J, Somavilla L, Cantarelli EB. 2015. Produção de mudas de cedro em função de tipos de recipiente e fontes de fertilizante. Pesquisa Florestal Brasileira 35(82): 153-158. DOI: https://doi.org/10.4336/2015. pfb.35.82.714.

Rossa UB, Angelo AC, Nogueira AC, Bognola IA, Pomianoski DJW, Soares PRC, Barros LTS. 2013; Fertilização de liberação lenta no crescimento de mudas de paricá em viveiro. Pesquisa Florestal Brasileira 33(75): 227-234. DOI: 10.4336/2013.pfb.33.75.429.

Santana JAS, Costa TLN, Silva BRF, Barbosa Junior VC, Costa MP, Canto JL. 2019. Utilização de recipientes biodegradáveis de bambu no desenvolvimento de mudas de Enterolobium contortisiliquum (Vell.) Morong. Brazilian Journal of Development 5(9): 15912-15921. DOI: https://doi. org/10.34117/bjdv5n9-157.

Thor K. 2019. Calcium-Nutrient and messenger. Frontiers in plant science 10(440): 1-7. DOI: https://doi.org/10.3389/ fpls.2019.00440. 